\title{
Article \\ Wild Mustard (Sinapis arvensis) Competition and Control in Rain-Fed Spring Wheat (Triticum aestivum L.)
}

\author{
Meisam Zargar *, Nyasha John Kavhiza, Maryam Bayat and Elena Pakina
}

check for updates

Citation: Zargar, M.; Kavhiza, N.J.; Bayat, M.; Pakina, E. Wild Mustard (Sinapis arvensis) Competition and Control in Rain-Fed Spring Wheat (Triticum aestivum L.). Agronomy 2021, 11, 2306. https://doi.org/10.3390/ agronomy 11112306

Academic Editor: Tran Dang Xuan

Received: 26 September 2021

Accepted: 14 November 2021

Published: 15 November 2021

Publisher's Note: MDPI stays neutral with regard to jurisdictional claims in published maps and institutional affiliations.

Copyright: (C) 2021 by the authors Licensee MDPI, Basel, Switzerland. This article is an open access article distributed under the terms and conditions of the Creative Commons Attribution (CC BY) license (https:/ / creativecommons.org/licenses/by/ $4.0 /)$.
Department of Agrobiotechnology, Institute of Agriculture, RUDN University, 117198 Moscow, Russia; njkavhiza@rocketmail.com (N.J.K.); maryambayat1313@yahoo.com (M.B.); e-pakina@yandex.ru (E.P.)

* Correspondence: zargar-m@rudn.ru

\begin{abstract}
Wild mustard (Sinapis arvensis L.) is a weed that frequently infests spring wheat (Triticum aestivum L.) fields in Moscow province, Russia. It is an annual broad leaf weed, which is indigenous throughout most parts of the globe and one of the most competitive weeds of spring cereal crops. In southern Russia it is emerging as an important crop competitor. Field trials focusing on herbicide timing and efficacy on wild mustard control and spring wheat yield in the Moscow region, Kashira and Baribino districts. A PRE glyphosate application to wheat regardless of fall or spring application timing favorably suppressed wild mustard in 2018. Weeds were not controlled in 2019 with the earliest application timings of glyphosate because weeds emerged late. In comparing fall and spring application timings, the formulated combination of (iodosulfuron/mesosulfuron/antidote mefenpyrdiethyl) at both field rates provided $80 \%$ weed control for all application timings and locations, and also resulting in the greatest spring wheat grain yield. Overall, herbicide treatments performed greater when they were in the fall than during the spring. Based on POST herbicide application, tribenuron-methyl provided the greatest wild mustard suppression $(75 \%)$ and also caused the highest reduction in wild mustard biomass (3.3 g), stem number (6), seed number (880) and germination percentage $(33 \%)$. When wild mustard was approximately 32 weeds $/ \mathrm{m}^{2}$ causedtotal wheat yield loss.
\end{abstract}

Keywords: herbicide; application timing; wild mustard control; glyphosate

\section{Introduction}

Wild mustard (Sinapis arvensis L.) is an annual cruciferous (Brassicaceae) weed widely distributed in Europe and around the world with a persistent seedbank [1,2], competitive growth habits, and high fecundity [3]. The height ranges from a few centimeters to around $80 \mathrm{~cm}$ depending on environmental conditions. Flower configuration is characterized by yellow clusters on long branches and silique-shaped pods containing four to eight spherical seeds each [4]. Flowering intensity ranges from a few flowers to several hundred flowers per individual (400-500). This species generally thrives in old abandoned fields as well as disturbed and nitrified habitats [5].

Differences in relative abundance among cruciferous weed species is attributed to the length of time from emergence, adaptability or their competitive ability against crops and other weeds [6]. Therefore, interspecific competition between wild mustard and cereal crops may be affected by factors such as weed biotype, time of emergence or time of removal, weed density, crop species, cultivar, crop density, as well as the environment $[7,8]$. Findings from previous studies have shown that the presence of such weeds has a greater impact on cereal yields in a wet spring than in a dry spring [8,9].

Wild mustard competition has been evaluated in winter cereals. Yield decreases of 26 and $27 \%$ in wheat and triticale, respectively, have been reported as a result of wild mustard competition, whereas barley yield decrease was only 3.5\%. Moreover, the wild mustard presence reduced total nitrogen content of wheat and triticale by 20 and $19 \%$, but this was not the case for barley [6]. Didon and Bostrom [8] found that uncontrolled wild mustard in barley, after several years of suitable control with POST herbicides, resulted yield losses 
ranging from 47 to $70 \%$. Unfortunately, many growers in Russia fail to realize that they have a wild mustard problem until the plants begin to bolt or produce flowers in the spring. Wild mustard species commonly infest wheat fields and can cause substantial crop losses if not appropriately controlled [10]. Hence, an effective weed control pays off in terms of decreased weed competition and reduced yield loss due to weed presence [11].

Rotating spring wheat with winter crops such as green-peas, canola, chick-peas, etc. and summer fallow allow for the use of non-selective active ingredients such as glyphosate before crop emergence, for the control of mustards [12]. There are several herbicides that can provide effective control against wild mustard, but these have to be applied before the plants are mature and in reproductive phase when begins rapid elongation of stem [13]. However, if mustards are present in the fall, growers should consider applying herbicides in the fall to control them.

The ALS-inhibiting herbicides serve as an effective alternative in controlling wild mustard and are also safe to use on wheat in the fall [10]. Furthermore, Lyon et al. [14] reported that effective ALS-inhibiting active ingredients for wild mustard control are metsulfuron, triasulfuron, propoxycarbazone, or pyroxsulam for wild mustard control in wheat cultivation [15]. They also revealed the synergistic nature of tribenuron, stating the possibility of surface tension reduction of tribenuron-methyl when another active ingredient is added, resulting in better penetration of the wild mustard leaves.

For winter wheat, various well established cultural practices are available for producers, including increasingwheat plant density and changing sowing date. On the contrary, cultural practices are less effective on spring wheat cultivation for weed control. In tandem with these facts, it is important to identify the optimal herbicide application time for glyphosate use in spring wheat, determine the most effective herbicides for wild mustard control before and after wheat emergence, and evaluate grain yield losses in spring wheat cultivation in response to wild mustard interference. Nevertheless, few studies have been done on PRE and -POST herbicide program for effective wild mustard control in spring and winter wheat in Russia. The failure to achieve satisfactory control of wild mustard in spring wheat (Triticum aestivum L.) by rotating herbicide program in the Moscow region, Russia, prompted the need to take up this study.

\section{Materials and Methods}

Experiments were conducted in wild mustard infested fields at Kashira $\left(42^{\circ} 59^{\prime} \mathrm{N}\right.$, $47^{\circ} 30^{\prime} \mathrm{E}$ and 135-m altitude) in the fall of 2018, and at two locations in the fall of 2019, Kashira and Baribeno $\left(42^{\circ} 58^{\prime} \mathrm{N}, 46^{\circ} 33^{\prime} \mathrm{E}\right.$ and $133-\mathrm{m}$ altitude). The soil at the Kashira region was a loamy sand ( $\mathrm{pH} 6.5$, organic matter $1.8 \%)$ and at the Baribino was a clay loam ( $\mathrm{pH} 7.0$ and organic matter $1.5 \%$ ).

Plots size was $2 \mathrm{~m}$ wide by $11 \mathrm{~m}$ long, comprising six crop rows (row width $=32 \mathrm{~cm}$ ). Seeds were sown with a Great Plains seeder (Great Plains Manufacturing, Inc.) at a target seeding rate of 1.6 million seeds ha ${ }^{-1}$. Compound fertilizer $\mathrm{N}_{12}-\mathrm{P}_{12}-\mathrm{K}_{36}$ was side banded and mid-row banded in the rows for all experimental plots at a rate of $230 \mathrm{~kg} \mathrm{ha}^{-1}$. Top dressing with urea was done at tillering phase at a rate of $140 \mathrm{~kg} \mathrm{~N} \mathrm{ha}^{-1}$. The fertilizer program was established by considering the soil characteristics.

$\mathrm{ACO}_{2}$ pressurized knapsack sprayer calibrated to spray at a rate of $230 \mathrm{~L} \mathrm{ha}^{-1}$ at 265 $\mathrm{kPa}$ through with four Turbo TeeJet 11,001 nozzles (TeeJet Technologies), spaced $55 \mathrm{~cm}$ apart was used to apply the herbicides. The average soil moisture content was at $75 \%$ field capacity during herbicide application.

Glyphosate Evaluation. The randomized complete block design with 3 replications was designated for the trials. The two central crop rows were used to investigate the differences in crop yields between treatments. Treatments included 2 controls, the weedy and weed-free plots plus six glyphosate application timings: three fall application timings and three spring application timings. The first treatment was applied 15 days after wild mustard emergence in the fall (mid- to late September). The next fall treatments were applied every 15 Days. The first spring treatment was applied 14 days after wild mustard 
germination (mid-April). Subsequent treatments were carried out every 14 days. All treatments were completed before spring wheat emergence. Glyphosate was applied at 430 ae ha $^{-1}$.

Evaluation of fall and spring application. An experiment with a randomized complete block design and split-plot design was arranged with three replicates to evaluate the efficacy differences between fall and spring herbicide treatments and to determine spring wheat yield losses after herbicide treatment. Herbicide treatments were sprayed the first time in the fall (15 October) to one-half of each block and the second time in the spring (25 April) to the other half of experimental blocks. Herbicide descriptions are provided in Table 1.

Table 1. List of herbicides and their rates, mode of action and chemical names.

\begin{tabular}{|c|c|c|c|}
\hline Active Ingredients & Mode of Action & $\begin{array}{l}\text { Concentration/ } \\
\text { Formulation }\end{array}$ & Chemical Names \\
\hline Fluroxypyr & Synthetic Auxins Inhibitor & $350 \mathrm{~g} / \mathrm{L} \mathrm{EC}$ & $\begin{array}{l}\text { [(4-amino-3,5-dichloro-6-fluoro-2- } \\
\text { pyridinyl)oxy]acetic acid }\end{array}$ \\
\hline Glyphosate & EPSP Synthase Inhibitor & SL $41 \%$ & N-(phosphonomethyl)glycine \\
\hline Tribenuron-methyl & ALS Inhibitor & $750 \mathrm{~g} / \mathrm{kg} \mathrm{WDG}$ & $\begin{array}{l}\text { 2-[[[[(4-methoxy-6-methyl-1,3,5-triazin-2- } \\
\text { yl)methylamino]carbonyl]amino]sulfonyl]benzoic acid }\end{array}$ \\
\hline $\begin{array}{l}\text { Iodosulfuron/mesosulfuron/ } \\
\text { antidote } \\
\text { mefenpyr-diethyl }\end{array}$ & ALS Inhibitor & 6/30/90 g/kg WDG & $\begin{array}{l}\text { 4-iodo-2-[[[[(4-methoxy-6-methyl-1,3,5-triazin-2- } \\
\text { yl)amino]carbonyl]amino]sulfonyl]benzoic } \\
\text { acid/2-[[[[[(4,6-dimethoxy-2- } \\
\text { pyrimidinyl)amino]carbonyl]amino]sulfonyl]-4- } \\
\text { [[(methylsulfonyl)amino]methyl]benzoic acid } \\
\text { /1-(2,4-dichlorophenyl)-4,5-dihydro-5-methyl-1H- } \\
\text { pyrazole-3,5-dicarboxylic acid }\end{array}$ \\
\hline Pyroxsulam & ALS Inhibitor & $45 \mathrm{~g} / \mathrm{L} \mathrm{OD}$ & $\begin{array}{l}\text { N-(5,7-dimethoxy[ } \\
\text {,2,4]triazolo[1,5-a]pyrimidin-2-yl)-2-methoxy-4- } \\
\text { (trifluoromethyl)-3-pyridinesulfonamide }\end{array}$ \\
\hline Mesosulfuron & ALS Inhibitor & $30 \mathrm{~g} / \mathrm{L} \mathrm{g} / \mathrm{L}$ OD & $\begin{array}{c}\text { 2-[[[[(4,6-dimethoxy-2- } \\
\text { pyrimidinyl)amino]carbonyl]amino]sulfonyl]-4- } \\
\text { [[(methylsulfonyl)amino]methyl]benzoic acid }\end{array}$ \\
\hline Metsulfuron & ALS Inhibitor & $600 \mathrm{~g} / \mathrm{kg}$ WDG & $\begin{array}{l}\text { 2-[[[[(4-methoxy-6-methyl-1,3,5-triazin-2- } \\
\text { yl)amino]carbonyl]amino]sulfonyl]benzoic acid }\end{array}$ \\
\hline Sulfosulfuron & ALS Inhibitor & $750 \mathrm{~g} / \mathrm{kg}$ WDG & $\begin{array}{c}\text { N-[[(4,6-dimethoxy-2-pyrimidinyl)amino]carbonyl]- } \\
\text { 2-(ethylsulfonyl)imidazol[1,2-a]pyridine-3- } \\
\text { sulfonamide }\end{array}$ \\
\hline
\end{tabular}

POST Application of Herbicides. Eight herbicides, a weedy and weed free control were used to assess the effect on wild mustard growth during the spring wheat growing season. Herbicides were sprayed at the end of May when spring wheat plants were at the four- to five-leaf stage and wild mustard plants were 5-8 cm tall with 5-7 leaves. The experimental design was a randomized complete block with three replications. Wild mustard data collected were stem number, seeds, biomass, and germination after treatment. Seven randomly selected wild mustard plants were collected in each plot.

The treatments were evaluated 18 days after herbicide application. Herbicide impact was visually estimated on a percentage scale from zero to $100 \%$, whereby zero denoted no visual effect and 100 indicated complete wheat plant death, based on European Weed Research Society (EWRS) evaluation, (Data not shown).

Statistical Analysis. Experimental data were analyzed using the GLIMMIX procedure of SAS (Version 9.4, SAS Institute Inc., Cary, NC, USA) using the mixed procedure with block as the random factor. The least squares mean statement in SAS with the Tukey adjustment at $p=0.05$ was used for comparison of means. Active ingredients and application times were evaluated fixed impacts when present in the experiments.

The effect of different wild mustard densities on spring wheat yield and wild mustard growth and fecundity were statistically evaluated. Wild mustard numbers were recorded in all plots in the spring and fall in each experiment taken randomly from two quadrats of 
$0.25 \mathrm{~m}^{2}$ in each plot. All aerial parts of the wild mustard weeds were harvested by hand in a $0.25 \mathrm{~m}^{2}$ quadrat. Wheat yield data were computed as the percentage of maximum yield to normalize results.

\section{Results and Discussion}

Glyphosate efficacy on wild mustard suppression. Glyphosate applied at Kashira in 2018 and spring 2019 resulted in statistically suitable wild mustard control. In the early fall of 2019 glyphosate was sprayed before a late-emerging wild mustard (Table 2). Consequently, suppression of wild mustard in late-September with glyphosate applications was less than it was with later application timings. The highest weed control was attained with the mid and late-October application, since such timing coincided with the emergence of most of the wild mustard and the population was greater. Weed control was less in Baribino region than it was in Kashira. Higher wild mustard density was observed in the fall season. Higher weed survival rates at Baribino can be ascribed to reduced leaf surface area available for herbicide action as a function of vegetative shielding. Hence, plant survival was directly proportion to weed population size, accounting for the differences between the two locations, as it was also noted in the studies by Sellers and Hickman [16] and Ostlie and Howatt [17].

Table 2. Wild mustard control by different glyphosate application (430 $\mathrm{g}$ ai ha $\left.{ }^{-1}\right)$ timings used pre-plant to spring wheat, at spring wheat harvest in two locations.

\begin{tabular}{lcc}
\hline \multirow{2}{*}{ Application Timing } & \multicolumn{2}{c}{ Wild Mustard Control\% } \\
\cline { 2 - 3 } & Kashira & Baribino \\
\hline Fall & $\mathbf{2 0 1 7 - 2 0 1 8}$ & $\mathbf{2 0 1 8 - 2 0 1 9}$ \\
Early September & $70 \mathrm{c}$ & $36 \mathrm{e}$ \\
Mid-September & $86 \mathrm{~b}$ & $77 \mathrm{~b}$ \\
Early October & $91 \mathrm{ab}$ & $82 \mathrm{a}$ \\
Spring & & \\
Early May & $93 \mathrm{a}$ & $49 \mathrm{~d}$ \\
Mid May & $96 \mathrm{a}$ & $64 \mathrm{c}$ \\
Early June & $91 \mathrm{ab}$ & $77 \mathrm{~b}$ \\
$p$-value & 0.0033 & 0.0093 \\
Coefficient of variation (\%) & 9.06 & 3.88 \\
\hline Means followed by different letters are significantly different by Tukey's Protected LSD $(p \leq 0.05)$.
\end{tabular}

According to the data analysis, the cold temperatures prevalent in Moscow during fall may have decreased the efficacy of glyphosate on wild mustard. Such climatic conditions, particularly cold temperatures along with snow, had low impact on wild mustard density at spring wheat harvest the following summer. For instance, glyphosate sprayed in earlyOctober resulted in poor wild mustard control 21 days after treatment $(<20 \%)$ compared with earlier herbicide treatment $(>85 \%)$, (data notshown), but the highest suppression was attained by each herbicide application timing $(>95 \%)$ in wheat harvest in summer 2019.

Wild mustard emergence after herbicide application can be addressed by integrating in the tank-mixture an herbicide with protracted persistence [17]. However, as Blackshaw [18] stated, late emerging weeds may not have significant negative impact on wheat yield potential, even if the weed population would be perpetuated.

Efficacy of herbicide application in fall and spring. Statistical findings proved that, wheat yield data and wild mustard control were significantly affected by location. Hence, Kashira and Boribino sites will be discussed separately.

Data analysis showed that both application timing and herbicides significantly affected wild mustard control at harvest in Baribino. It was observed at preharvest that fall-applied active ingredients had better control results ( $84 \%$ ) than spring-applied herbicides $(74 \%)$ on average (Table 3), corresponding with the results obtained by Ostlie and Howatt [17] in wheat cultivation. Wild mustard suppression by (iodosulfuron/mesosulfuron/antidote 
mefenpyr-diethyl) was $91 \%$ and higher across application timings. Weed control by (iodosulfuron/mesosulfuron/antidote mefenpyr-diethyl) at 21 days was $83 \%$, less than the preharvest investigation (data notshown).

Table 3. Wild mustard control and wheat grain yield after fall and spring herbicide applied preplant at Baribino 2019.

\begin{tabular}{|c|c|c|c|c|c|}
\hline \multirow{2}{*}{ Active Ingredients } & \multirow{2}{*}{$\begin{array}{c}\text { Field Rate } \\
\text { g ai ha }{ }^{-1}\end{array}$} & \multicolumn{2}{|c|}{ Wild Mustard Control\% } & \multicolumn{2}{|c|}{ Wheat Grain Yield kg ha ${ }^{-1}$} \\
\hline & & Fall & Spring & Fall & Spring \\
\hline Weedy & - & - & - & $2960 \mathrm{f}$ & 3320 ef \\
\hline Weed free & - & - & - & $6810 \mathrm{a}$ & $5690 \mathrm{a}$ \\
\hline Pyroxsulam & 10 & $62 \mathrm{~d}$ & $48 \mathrm{f}$ & $3860 \mathrm{~d}$ & 3850 de \\
\hline Pyroxsulam & 17 & $82 \mathrm{bc}$ & $58 \mathrm{e}$ & $4040 \mathrm{~cd}$ & 3840 de \\
\hline $\begin{array}{l}\text { Iodosulfuron/mesosulfuron/antidote } \\
\text { mefenpyr-diethyl }\end{array}$ & $3 / 11 / 35$ & 97 a & $91 \mathrm{ab}$ & $5650 \mathrm{~b}$ & $4420 \mathrm{~b}$ \\
\hline $\begin{array}{l}\text { Iodosulfuron/mesosulfuron/antidote } \\
\text { mefenpyr-diethyl }\end{array}$ & $5 / 15 / 45$ & $97 \mathrm{a}$ & $95 \mathrm{a}$ & $6860 \mathrm{a}$ & $4270 \mathrm{bc}$ \\
\hline Tribenuron-methyl & 20 & $89 \mathrm{~b}$ & $80 \mathrm{c}$ & 3570 de & $4160 \mathrm{bcd}$ \\
\hline Glyphosate & 430 & $79 c$ & $74 \mathrm{~d}$ & $4530 \mathrm{c}$ & $4030 \mathrm{~d}$ \\
\hline Metsulfuron & 14 & $83 \mathrm{bc}$ & $75 \mathrm{~d}$ & $3840 \mathrm{~d}$ & $3505 \mathrm{e}$ \\
\hline$p$-value & - & 0.02 & 0.0011 & 0.01 & 0.002 \\
\hline Coefficient of variation (\%) & - & 6.9 & 9.4 & 2.5 & 8.8 \\
\hline
\end{tabular}

Means followed by different letters are significantly different by Tukey's Protected LSD $(p \leq 0.05)$.

The reduced dose of pyroxsulam provided poor wild mustard control in Baribino. On the other hand, with the exception of pyroxsulam, wild mustard suppression with all fall-applied active ingredients was $82 \%$ or even better. The least effective weed control during fall and spring applications were noted in both field rates of pyroxsulam (Table 3). Other herbicides examined in this study indicated a $5-9 \%$ reduction between fall and spring applications, which corresponded with decreases in spring wheat yield.

Wheat grain yield in Boribino was affected by the herbicide applications. Application timing $(p>0.05)$ and the interaction of application timing and active ingredients $(p>0.05)$ were not statistically significant on wheat grain yield. In our study, it was observed that wheat grain yield was influenced more by herbicide applications than was indicated by wild mustard suppression (Table 3), our findings were consistent with the results achieved by Ostlie and Howatt [17], they stated that the impacts of herbicide use were more pronounced on wheat productivity than the effects of weed suppression in the field. The use of the least injurious herbicide substantially improved overall grain yield. Moreover, tribenuron-methyl as spring applied treatment and enhanced wheat yield compared to the fall treatment. Grain yields from both rates of (iodosulfuron/mesosulfuron/antidote mefenpyr-diethyl), were almost similar to the weed-free plot for application timings (Table 3). Tribenuron-methyl and the formulated product of (iodosulfuron/mesosulfuron/antidote mefenpyr-diethyl) have been recently used to control different broadleaf weed species in Moscow region, Russia [19-21].

At the field in Kashira, herbicide treatment and application timing had significant effect on wild mustard suppression, but no interaction was established between them (Table 4). Preharvest weed control trials in Kashira showed that fall-applied herbicide treatments was better than the spring-application. Wild mustard plants succumbed more to spring applied tribenuron-methyl than they were after a fall treatment. However, wild mustard control with pyroxsulam at both rates and metsulfuron in both seasons was only $41-65 \%$.

Wheat yield was not negatively affected by different treatments at Kashira $(p>0.05)$, unlike Baribino (Table 4). The low impact of wild mustard on grain yield is due to the low population of wild mustard in the field. 
Table 4. Wild mustard control and wheat grain yield after fall and spring herbicide applied preplant at Kashira 2019.

\begin{tabular}{|c|c|c|c|c|c|}
\hline \multirow{2}{*}{ Active Ingredients } & \multirow{2}{*}{$\begin{array}{c}\text { Field Rate } \\
\text { g ai ha-1 }\end{array}$} & \multicolumn{2}{|c|}{ Wild Mustard Control\% } & \multicolumn{2}{|c|}{ Wheat Grain Yield kg ha ${ }^{-1}$} \\
\hline & & Fall & Spring & Fall & Spring \\
\hline Weedy & - & - & - & $4170 \mathrm{c}$ & 4220 \\
\hline Weed free & - & - & - & 4790 a & 4630 a \\
\hline Pyroxsulam & 10 & $60 \mathrm{~cd}$ & $55 c$ & $4680 \mathrm{ab}$ & $4580 \mathrm{~b}$ \\
\hline Pyroxsulam & 17 & $65 c$ & $49 \mathrm{~d}$ & $4660 \mathrm{ab}$ & $4510 \mathrm{~b}$ \\
\hline $\begin{array}{l}\text { Iodosulfuron/mesosulfuron/antidote } \\
\text { mefenpyr-diethyl }\end{array}$ & $3 / 11 / 35$ & $85 \mathrm{~b}$ & $84 \mathrm{a}$ & 4790 a & $4560 \mathrm{~b}$ \\
\hline $\begin{array}{l}\text { Iodosulfuron/mesosulfuron/antidote } \\
\text { mefenpyr-diethyl }\end{array}$ & $5 / 15 / 45$ & 94 a & 80 a & 4770 a & $4510 \mathrm{~b}$ \\
\hline Tribenuron-methyl & 20 & $63 c$ & $78 \mathrm{ab}$ & $4560 \mathrm{~b}$ & $4540 \mathrm{~b}$ \\
\hline Glyphosate & 430 & $82 \mathrm{~b}$ & $44 \mathrm{de}$ & $4550 \mathrm{~b}$ & $4640 \mathrm{a}$ \\
\hline Metsulfuron & 14 & $63 c$ & $41 \mathrm{e}$ & $4690 \mathrm{ab}$ & $4590 \mathrm{ab}$ \\
\hline$p$-value & - & 0.060 & 0.0051 & 0.01 & 0.099 \\
\hline Coefficient of variation (\%) & - & 5.5 & 10.9 & 5.9 & 6.7 \\
\hline
\end{tabular}

Means followed by different letters are significantly different by Tukey's Protected LSD ( $p \leq 0.05)$.

Different herbicide efficacy was attained by pre-plant application of active ingredients. The premixed herbicide (iodosulfuron/mesosulfuron/antidote mefenpyr-diethyl) had better effect than the other herbicide treatments when evaluating end of season control in Baribino location. For the 2-year research period, (iodosulfuron/mesosulfuron/antidote mefenpyr-diethyl) had greater weed control efficacy than other herbicides except tribenuronmethyl at Kashira. Applying this herbicide in the fall had better results in both locations, than the spring application. Conversely, tribenuron-methyl had better results when used in spring at Kashira and resulted ingreater yield when applied in spring at Baribino. Montazeri [22] reported that application of tribenuron-methyl herbicides had a synergistic effect in controlling wild oat (Avena ludoviciana Durieu.) and wild mustard (Sinapis arvensis L.) in wheat cultivation.

POST herbicide application impact on wild mustard and spring wheat yield. Wild mustard control percent ranged from 30 to $75 \%$ across both locations depending on the herbicide applications (Table 5). Wild mustard control was the highest for tribenuronmethyl treatment. All other active ingredients provided similar wild mustard control in the range of 49 to $61 \%$ with the exception of fluroxypyr. However, with 49 to $61 \%$ wild mustard control, relying on the above mentioned treatments cannot be recomended as a sole method of weed control in wheat cultivation.

Table 5. Wild mustard control in different aspects in each plot, 28 days after treatment combined across regions.

\begin{tabular}{|c|c|c|c|c|c|c|}
\hline Active Ingredients & Field Rate & Weed Control & Biomass & Seeds & Germination & Stem \\
\hline & g ai ha ${ }^{-1}$ & $\%$ & g & No. & $\%$ & No. \\
\hline Weedy & - & $0 \mathrm{e}$ & $38.2 \mathrm{a}$ & $6880 \mathrm{a}$ & $69 a$ & $18 \mathrm{a}$ \\
\hline Fluroxypyr & 144 & $30 \mathrm{~d}$ & $23.2 \mathrm{~b}$ & $4570 \mathrm{~b}$ & $55 \mathrm{bc}$ & $12 \mathrm{~b}$ \\
\hline Tribenuron-methyl & 20 & $75 \mathrm{a}$ & $3.3 \mathrm{f}$ & $880 \mathrm{~g}$ & $33 \mathrm{~d}$ & $6 \mathrm{~d}$ \\
\hline Pyroxsulam + mesosulfuron & $10+12$ & $50 \mathrm{c}$ & $12.4 \mathrm{de}$ & $2650 \mathrm{~cd}$ & $71 \mathrm{a}$ & $9 c$ \\
\hline Pyroxsulam + mesosulfuron & $17+16$ & $55 \mathrm{bc}$ & $11.9 \mathrm{e}$ & $1110 \mathrm{f}$ & $51 \mathrm{bc}$ & $9 c$ \\
\hline Mesosulfuron & 12 & $49 c$ & $15.2 \mathrm{c}$ & $2150 \mathrm{~d}$ & $48 \mathrm{c}$ & $11 \mathrm{~b}$ \\
\hline Mesosulfuron & 16 & $50 \mathrm{c}$ & $12.0 \mathrm{e}$ & $1430 \mathrm{e}$ & $52 \mathrm{bc}$ & $9 c$ \\
\hline Metsulfuron & 14 & $55 \mathrm{bc}$ & $13.2 \mathrm{~d}$ & $2790 \mathrm{c}$ & $58 \mathrm{~b}$ & $12 \mathrm{~b}$ \\
\hline Sulfosulfuron & 28 & $61 \mathrm{~b}$ & $11.6 \mathrm{e}$ & $1170 \mathrm{f}$ & $59 \mathrm{~b}$ & $8 \mathrm{~cd}$ \\
\hline$p$-value & - & 0.020 & 0.0001 & 0.022 & 0.006 & 0.0011 \\
\hline Coefficient of variation (\%) & - & 5.9 & 9.1 & 2.9 & 8.9 & 10.8 \\
\hline
\end{tabular}


Tribenuron-methyl generally resulted in the least number of stems per plant, one third of the stems in the weedy control plots. Thus, stems per plant were similar to that of the weedy control when fluroxypyr, low dose of mesosulfuron, and metsulfuron were applied. Higher wild mustard biomass $\left(38.2 \mathrm{~g} / \mathrm{m}^{2}\right)$ was observed in the weedy control plots with the greatest population (Table 5). Wild mustard biomass was $10 \%$ of the biomass of nontreated plots when tribenuron-methyl was applied. Wild mustards biomass was similar for all other herbicide treatments except fluroxypyr application.

Wild mustard produced 6880 seeds in nontreated control plots. Fluroxypyr decreased wild mustard seed production 35\% compared to the weedy control, whilst tribenuronmethyl decreased wild mustard seed production by $87 \%$ compared to the weedy control.

According to the analyzed data, only tribenuron-methyl treated weeds had statistically lower seed germination percentage than the nontreated plots. Based on seed setting and germination percentage after herbicide application, tribenuron-methyl treated wild mustard produced 250 viable seeds plant ${ }^{-1}$. The next lowest seed set was attained with a low dose of pyroxsulam + mesosulfuron (data not shown). (Table 5). Wild mustard suppression with tribenuron-methyl application was higher than it was with the other treatments in this study. Except tribenuron-methyl, wild mustard control with metsulfuron, sulfosulfuron and the higher rate of pyroxsulam + mesosulfuron was similar. Overall, tribenuron-methyl also significantly diminished wild mustard to its lowest seeds, stem, and germination. The results are agreeable with previous findings in other crops $[3,23,24]$.

The necessity of POST and -PRE application of various herbicide treatments with sustainable activity on weed control was evaluated. Therefore, it is critical for spring wheat to be free of weeds that can interfere with this crop. For sustainable wild mustard control, the integration of POST and -PRE herbicide application is recommended [25]. For instance, Johnson et al. [9] reported a broad spectrum weed suppression can be attained through the use of tribenuron and pyroxsulam which are both ALS inhibiting active ingredients.

Due to the high germination potential of the wild mustard in the early years, preventive steps can be applied when wild mustard first appears in the field. Preventive methods include effective control of wild mustard before spring wheat sowing with herbicide or tillage to allow the application of effective herbicides during the growing season for weed management. Most of the registered broad leaf herbicides for wheat are among ALS-inhibiting products, which may promote development of resistance in weeds if used frequently year by year. Hence, other herbicides with the different mechanisms of action should be applied in a crop rotation to avoid herbicide resistance. Generally, treatments containing tribenuron-methyl and formulated mixture of (iodosulfuron/mesosulfuron/antidote mefenpyr-diethyl) provided better efficacy on wild mustard control in all field experiments conducted in both locations, and proved to be safe for use in spring wheat. This research suggests that the application of tribenuron-methyl and (iodosulfuron/mesosulfuron/antidote mefenpyr-diethyl) whould provide an effective management of wild mustard resistant to herbicides in spring wheat. Additional research is needed to illustrate the response of subsequent crops to the herbicide residue after spring wheat in the form of crop rotation in Moscow region.

Author Contributions: Conceptualization, M.Z. Methodology, data collection and original data analysis: M.Z. and M.B. Data presentation, writing, reviewing and editing N.J.K. and E.P. All authors have read and agreed to the published version of the manuscript.

Funding: This research received no external funding.

Institutional Review Board Statement: Not applicable.

Informed Consent Statement: Not applicable.

Data Availability Statement: The data presented in this study are available in article. 
Acknowledgments: The publication has been prepared with the support of the RUDN University Program 5-100.

Conflicts of Interest: No potential conflict of interest was reported by the authors.

\section{References}

1. Ghersa, C.M.; Martinez-Ghersa, M.A. Ecological correlates of weed seed size and persistence in the soil under different tilling systems: Implications for weed management. Field Crop. Res. 2000, 67, 141-148. [CrossRef]

2. Van Acker RC Weed biology serves practical weed management. Weed Res. 2009, 49, 1-5. [CrossRef]

3. Gherekhloo, J.; Hatami, Z.M.; Alcántara-de la Cruz, R.; Sadeghipour, H.R.; De Prado, R. Continuous Use of Tribenuron-Methyl Selected for Cross- Resistance to Acetolactate Synthase-inhibiting Herbicides in Wild Mustard (Sinapis arvensis). Weed Sci. 2018, 66, 424-432. [CrossRef]

4. Luzuriaga, A.L.; Escudero, A.; Olano, J.M.; Loidi, J. Regenerative role of seed banks following an intense soil disturbance. Acta Oecol. 2005, 27, 57-66. [CrossRef]

5. Luzuriaga, A.L.; Escudero, A.; Pe Rezgarcia, F. Environmental maternal effects on seed morphology and germination in Sinapis arvensis (Cruciferae). Weed Res. 2006, 46, 163-174. [CrossRef]

6. Dhima, K.; Eleftherohorinos, I. Wild Mustard (Sinapis arvensis L.) Competition with Three Winter Cereals as Affected by Nitrogen Supply. J. Agron. Crop. Sci. 2005, 191, 241-248. [CrossRef]

7. Luzuriaga, A.L.; Escudero, A.; Loidi, J. Above-ground biomass distribution among species during early old-field succession. J. Veg. Sci. 2002, 13, 841-850. [CrossRef]

8. Didon, E.M.U.; Bostrom, U. Growth development of six barleys (Hordeum vulgare ssp. vulgare L.) cultivars in response to a model weed (Sinapis alba L.). J. Agron. Crop Sci. 2003, 189, 409-417. [CrossRef]

9. Redlick, C.; Duddu, H.S.N.; Syrovy, L.D.; Willenborg, C.J.; Johnson, E.N.; Shirtliffe, S.J. Effect of Seeding Rate on Dose Response of Wild Mustard (Sinapis arvensis) to Fluthiacet-Methyl. Weed Sci. 2017, 65, 525-533. [CrossRef]

10. Peachey, E. (Ed.) Pacific Northwest Weed Management Handbook; Oregon State University: Corvallis, OR, USA, 2017.

11. Kolb, L.N.; Gallandt, E.R. Modelling population dynamics of Sinapis arvensis in organically grown spring wheat production systems. Weed Res. 2013, 53, 201-212. [CrossRef]

12. Lyon, D.J.; Klein, R.N.; Wilson, R.G. Blue Mustard Control; University of Nebraska-Lincoln Extension: Lincoln, NE, USA, 2006.

13. Callihan, B.; Brennan, J.; Miller, T.; Brown, J.; Moore, M. Mustards in Mustards: Guide to Identification of Canola, Mustard, Rapeseed, and Related Weeds; University of Idaho: Moscow, Russia, 2000.

14. Lyon, D.J.; Burke, I.C.; Campbell, J.M. Integrated Management of Mustard Species in Wheat Production Systems; Washington State University Extension: Washington, DC, USA, 2018.

15. Aliverdi, A.; Rashed Mohasel, M.R.; Zond, E.; Nasiri, M. Increased foliar activity of clodinafop-propargyl and/or tribenuronmethyl by surfactants and their synergistic action on wild oat (Avena ludoviciana) and wild mustard (Sinapis arvensis). Weed Biol. Manag. 2009, 9, 292-299. [CrossRef]

16. Sellers, B.A.; Hickman, M.V. Effects of soil amendments on herbicide efficacy and leaching. Weed Technol. 2001, 15, 686-696. [CrossRef]

17. Ostlie, M.H.; Howatt, K.A. Downy Brome (Bromus tectorum) Competition and Control in No-Till Spring Wheat. Weed Technol. 2013, 27, 502-508. [CrossRef]

18. Blackshaw, R.E. Downy brome (Bromus tectorum) density and relative time of emergence affects interference in winter wheat (Triticum aestivum). Weed Sci. 1993, 41, 551-556. [CrossRef]

19. Luchinskiy, A.S.; Luchinskiy, S.I.; Kalashnikov, V.A.; Makoveev, A.V. Suppression of field thistle-Cirsium arvense in sunflower crops. Nauch. Zhurn. KubGAU 2017, 33, 1-10. (In Russian) [CrossRef]

20. Zargar, M.; Bayat, M.; Lyashko, M.; Chauhan, B. Postemergence Herbicide Applications Impact Canada Thistle Control and Spring Wheat Yields. Agron. J. 2019, 111, 2874-2880. [CrossRef]

21. Zargar, M.; Bayat, M.; Romanova, E.; Izadi-Darbandi, E. POST herbicide programs utilizing tribenuron for cleavers (Galium aparine L.) control in winter wheat cultivars. Arch. Agron. Soil Sci. 2019, 66, 1235-1243. [CrossRef]

22. Montazeri, M. Interaction of tribenuron methyl and graminicides in wheat. In Proceedings of the 1995 Brighton Crop Protection Conference-Weeds, Brighton, UK, 20-23 November 1995; Volume 2, pp. 753-756.

23. Cruz-Hipolito, H.E.; Rosario, J.; Ioli, G.; Osuna, M.D.; Smeda, R.J.; González-Torralva, F.; De Prado, R. Resistance mechanism to tribenuron methyl in white mustard (Sinapis alba) from southern Spain. Weed Sci. 2013, 61, 341-347. [CrossRef]

24. Ntoanidou, S.; Madesis, P.; Diamantidis, G.; Eleftherohorinos, I. Trp574 substitution in the acetolactate synthase of Sinapis arvensis confers crossresistance to tribenuron and imazamox. Pest. Biochem. Physiol. 2017, 142, 9-14. [CrossRef] [PubMed]

25. Johnson, E.N.; Wang, Z.; Geddes, C.M.; Coles, K.; Hamman, B.; Beres, B.L. Pyroxasulfone Is Effective for Management of Bromus spp. in Winter Wheat in Western Canada. Weed Technol. 2018, 32, 739-748. [CrossRef] 